\title{
Muhammadiyah Political Theology on the Religiosity Moderation in Indonesia
}

\author{
Isa Anshori ${ }^{1 *}$ \\ ${ }^{1}$ Faculty of Islamic Studies Muhammadiyah University of Surabaya, Surabaya, Indonesia \\ *Corresponding author. Email: i.anshori@fai.um-surabaya.ac.id
}

\begin{abstract}
This research is aimed to reveal how the Muhammadiyah's theological concept encompassing these following issues. Firstly, the issue of national politics related to the basic discourse of the Indonesian State. Secondly, the theological concepts governing the multicultural social relations of Indonesian society, in terms of religion, ethnicity, culture and customs regarding its religious moderation. This paper used various information tracking and documentation on various theological attitudes of Muhammadiyah related to religious moderation discourse in Indonesia include the decisions of the results of the Muhammadiyah congress, tanwir, and various studies produced by various Muhammadiyah organization, as well as books published by the central board of Muhammadiyah. Philosophical approaches are used to analyze the critique concept and perspective of Muhammadiyah's political theology. This paper finds the theological concept is certainly as part of Muhammadiyah's religious transformation in response to various forms of ideology that are not in accordance with Muhammadiyah's manhaj and the pluralistic character of Indonesian society.
\end{abstract} Keywords: Muhammadiyah, political theology, religiosity moderation

\section{INTRODUCTION}

As a religious organization movement, Muhammadiyah which has been more than a century old and has millions of participants both in Indonesia and abroad, is a social capital and material that can change the social, political, religious, economic and cultural patterns of the Indonesian people. Muhammadiyah's image cannot be separated from the theological foundation which forms its core fundamentals. Even, the name and ethics of Muhammadiyah are reflections of its patterned theology; purification, [1] reformist, [2] modern [3] and Transformative [4]. In the language of Mitsuo Nakamura, Muhammadiyah has many faces, doctrinaire with systematic theology from the Qur'an and Hadith as a moral reference, seeming fanatical and exclusive from the outside but actually tolerant [5].

The typology of the Muhammadiyah religious movement characterized by dakwah (purification) and renewal has its greatest challenges in the millennial era marked by the rapid development of science and information technology with respect to the values of religious and cultural pluralism in the world today. Uncontrolled purification will push religious movements into the spectrum of orthodoxy and exclusivity. On the other hand, the vital reformation continues to demand and encourage Muhammadiyah to adapt and innovate in addressing the progress of world civilization through the development of technology and information that is getting more accessible and freer.

Indonesia is a country endowed with abundant wealth through ethnic, religious and cultural heterogeneity. The era of globalization which is marked by the openness of technology and information not only brings positive values, but also new challenges, especially for the flourishing of the global ideology and the emergence of transnational movements (ideology, politics, religion and culture). This situation will surely cause resistance to the State and nation of Indonesia. As a country that has a diversity of religions and cultures, Indonesia is in need of an adhesive tool for the integrity of the values of state and nationality. Therefore, a joint commitment is needed for all Indonesian people to maintain that integrity.

One of the main issues is the efforts that have been and are being carried out by the Indonesian government through strengthening and implementing religious moderation. Strengthening religious moderation in Indonesia is carried out through three main strategies; socialization, institutionalization and integration, which is contained in the National Medium-Term Development Plan (RPJMN) 2020-2024. The indicators of achievement are; firstly, national commitment, secondly, tolerance, thirdly nonviolence, fourthly accommodating of local culture [5].

This research is aimed to reveal how the Muhammadiyah's theological concept encompassing these following issues. Firstly, the issue of national politics related to the basic discourse of the Indonesian State. Secondly, the theological concepts governing the multicultural social relations of Indonesian society, in terms of religion, ethnicity, culture and customs regarding its religious moderation.

To find out how the political theology of Muhammadiyah is related to religious moderation in Indonesia, this study uses various information tracking and documentation on various theological attitudes of Muhammadiyah related to religious moderation discourse in Indonesia.

The information and documentation intended in this study are the various official documents of the organization, which include the decisions of the results of the Muhammadiyah congress, tanwir, and various studies produced by various assemblies and institutions under the 
Muhammadiyah organization, as well as books published by the central board of Muhammadiyah. In this article, some of the Muhammadiyah's decisions are the focus of analysis, namely; the decision of the 47th Congress in Makassar, and tanwir Muhammadiyah in Bali in 2002. This research is descriptive qualitative using a philosophical approach.

Philosophical approaches are used to analyze the critique concept and perspective of Muhammadiyah's political theology. Theological perspective is intended to describe Muhammadiyah's substantive-textual responses to social problems that arise based on the Islamic faith system which becomes the moral reference of Muhammadiyah's religion. Its function which is legitimate and solute means that the structure and actions of social groups are manifestations and commitments to certain belief systems [6]. Moreover, the dialectics between Muhammadiyah and social reality can be traced by constructing a system of data and knowledge that is built related to religious moderation in Indonesia. To understand this, the sociological approach to knowledge as an effort to uncover the links between thinking, social praxis, social context and social determination [7], is used as an analysis tool in this article.

\section{RESULTS AND DISCUSSION}

\subsection{Progressing Islam: Theological Transformation and Reconstruction}

The history of Muhammadiyah as a da'wah and tajdid movement has begun since its inception in Yogyakarta in 1912 by KH. Ahmad Dahlan. Progressive Islam was introduced at the 46th Muhammadiyah Conference in 2010 in Yogyakarta and 47th in Makassar with the theme "Enlightenment Movement Towards Progressive Indonesia". It was stated that the enlightenment movement (tanwir) was a praxis of Islam that was progressing to liberate, empower and advance the lives. Enlightenment publicity is the path (methodology) while Islam is progressing as a value, ethos and spirit for the ideals of Progressive Indonesia. It is in line with the actualization of the Proclamation and the purpose of the Indonesian State as stipulated in the opening of the 1945 Constitution namely; independent, united, sovereign, just and prosperous. In the conception of Muhammadiyah, this is emphasized as a missionary and tajdid movement that carries the mission of Islam as the main civilization (al-Hadarah al-fadilah) [8]. Formally, "Progressive Islam" is the substance of the Muhammadiyah Islamic viewpoints contained in the second century of Muhammadiyah's main statement.

Progressive Islam is an essential and systematic thought, in which Muhammadiyah as a reformation movement continues to take part in advancing the lives of the people, nation and the world of universal humanity. In this case, the theological outlook of Islam has a progressive fundamental reference to the teachings of Islam (al-Qur'an and Sunnah) as a role model of movement as well as the results of the systematization of the early generation which has theological, historical, and ideological grounds. Due to this reason, the Progressive Islamic movement has in fact been attached to Muhammadiyah as a da'wah movement and the tajdid movement.

The transformation of the Muhammadiyah renewal movement is the link of the enlightenment movement of the condition of the colonized Muslims, and at the same time lags in many aspects of life. Therefore, Muhammadiyah presents Islam as an advanced religion and advances the civilization of humanity as the basic character of Islam (din al-hadarah). When there were still many parties struggling in classical fiqh debates (worship mahdhah), Muhammadiyah gave an example with practical work by actualizing Islam through renewal and enlightenment. The actualization in the field of thought, education is done by establishing educational institutions ranging from early age to higher education, in the health sector is done by establishing hospital, in the field of social services is done by establishing orphanages, and the last but not least, in the field of human empowerment is done by empowering the people and strengthening the economy of the people.

\subsection{Religiosity Moderation: From Commitment to the Nationality to the local culture}

\subsubsection{Darul Ahdi wa Shahadah}

There are several Concepts of Islamic Progress related to Islamic views (theology) in relation to issues of national politics and cultural strategies, among others; Darul Ahdi wa as Shahadah,

Political theology is a movement that emerged in the 1960s that sought to develop new hermeneutics in theological thought. Political theology emphasized more reflective efforts on social and historical contexts. It has meaning which are: first, the use of religious symbols, both implicitly and explicitly in interpreting, legitimating and criticizing political problems, events, systems, or units; second, political theology acts as a fundamental theology that analyzes the relationship between political patterns and religious beliefs with the aim of revealing the meaning, truth and practice of religious symbols.

Muhammadiyah's political theology is Muhammadiyah's ideas and attitudes in responding to all national political problems, where politics is not only interpreted as an effort to gain power and fight for seats in government or parliament alone. The political theology is a reflection and criticism of social and politics in the framework of modernity with the whole the problems that lead to socialreligious praxis. Therefore, Muhammadiyah's political theology has a function to legitimize and criticize political reality both implicitly and explicitly.

The conceptual formulation of Darul Ahdi wa shahadah in the 2014 milestone [9] is the Muhammadiyah's view of the national life of the unitary state of the Republic of Indonesia (NKRI) which is upheld on noble philosophy and in line with the values of Islamic teachings. The basis of the Pancasila State is the result of consensus of all elements of the nation (darul ahdi) and at the same time as a place of proof or testimony (Dar al-Shahadah) to create a safe and 
peaceful State. [10] This theological formulation is a response to the rise of transnational religious or nonreligious ideologies that is developed in Indonesia after the reformation era, which tried to sue againts the foundations of Indonesian national philosophy and even tried to make changes through the constitutional channels.

Muhammadiyah's role in establishing the unitary state of Indonesia has begun since the inception of Indonesia. Several leaders of the Muhammadiyah were actively involved in the history of the movement and preparation for the founding of Indonesia, including; KH. Mas Mansur was involved as a 'series of four' with Ir. Soekarno, M. Hatta, and $\mathrm{Ki}$ Hajar Dewantara who initiated Indonesian independence during the Japanese occupation. Likewise, three other Muhammadiyah figures, Ki Bagus Hadi Kusumo, Prof. Kahar Muzakir, and Mr. Kasman Singodimejo were active in the Indonesian Independence Business Preparatory Agency (BPUPKI) and the Indonesian Independence Preparatory Committee (PPKI). The historical record that is very important for the integrity of the Unitary Republic of Indonesia is the role of Ki Bagus Hadi Kusumo and Mr. Kasman Singo Dimejo with his religious and statesmanship affirmed the abolition of the seven words in the Jakarta charter in order to preserve the integrity of the Indonesian nation [9].

After the proclamation of the Unitary State of the Republic of Indonesia and the adoption of Pancasila as the basis of the State, Muhammadiyah had the view that the Pancasila State was upheld on a noble national philosophy in line with Islamic teachings [9]. This nationalist view is in line with the Islamic idea of the ideal state, which is a good country and is in the mercy of God, a country that is blessed because of its people of faith and piety (al-Araf: 96), worship and prosperity (ad-Dzariyat: 56, Hud : 61), carrying out the function of the Caliphate and not causing damage (alBaqaraah; 11, 30), having a relationship with God and others (Ali Imran: 112), developing relationships between components of the nation and humanity that are equal and qualified with taqwa (al- Hujurat: 13), and become a civilized and dignified nation (Ali Imran: 110).

In the view of the Muhammadiyah, Pancasila as a dar shahadah or the State of Pancasila is a place to witness and prove themselves in filling and building national life. In the Pancasila State, as the dar shahadah of the Muslims, they must be ready to compete (fastabiqul khairat) to fill and advance the life of the nation with all good creations and innovations.

\subsubsection{Tolerance and Non-Violence}

Issues regarding tolerance and anti-violence can be found in the document of the results of the 47th Muhammadiyah congress in 2015 in Makassar on strategic issues, which include among others about "moderate religion in religious aspects (wasatiyah)" and "tolerant religion" in the issue of nationality. It can also be found in the 1956 Muhammadiyah Palembang conference document which was ratified in 1962 and became the official formulation of the Muhammadiyah Personality. Theological concept of wasatiyah is a theological response to the religious understanding and behavior of extreme Indonesian religious (takfiri groups). Moderation in the form of tolerance and anti-violence preaching has become part of the Muhammadiyah missionary sphere.

\subsubsection{Accommodating Local Culture}

In Tanwir Muhammadiyah 2002 in Bali, the concept of cultural da'wah was stated as a da'wah to answer the challenges of the times. The act was carried out in the form of appreciation to the culture / culture that was developing, as well as accepting and creating a new and better culture in accordance with the message of Islam. Islam carries a message as an understanding of lil alamin that allows to the change of da'wah strategy into a more dynamic, creative and innovative way [11].

The preaching of cultural literature is established firmly on universal values, local wisdom and prevention of evil deeds by paying attention to the uniqueness of human nature individually and socially. Practically, it is done through an encouraging and easy way for the upholding of Islamic values in various aspects of social, economic, political and cultural life [11].

In the study of intellectual history, particularly the religious movement, John Obert Voll offered the theory of continuity and its main changes in analyzing the Islamic resurgence movement (Islamic resurgence) through three dimensions which are local cultural approaches, global influencers and internal Islamic dynamism. Muhammadiyah's political theology also can be sensed through perspective of Michel Foucault (1926-1984) in the study of intellectual history. Foucault intellectual history is always marked by the transformation (Transformation), shift (Shifting) and the epistemic rupture of thought or concept. The theological concept that has been built by Muhammadiyah in responding to the problems of religious moderation in Indonesia aforementioned, can be explained by the historical alliance. It was initiated by Antonio Gramsci where the social relations system is a complex interaction of various social forces, political relations, ideas and history. In this case, religious thought (the concept of political theology) produced by Muhammadiyah (at the super-structure level) as a result of interactions in the sociopolitical relations system that involves various historical forces will be able to change people's religious behavior (basic structural level) and religious moderation in Indonesia.

Muhammadiyah's political theology is not a traditional theological concept, although the concept of traditional theology was a concept that was born in a historical context, where the concept of God's transcendence was affected by sects, cultures and the old belief systems. Neverthless, the dialectical nature of words, as in the classical sense is limited to "logos" and "Theos" (Kalam science), whose conceptual framework is arranged in the conditions, languages and categories of the time. Muhammadiyah's theology is better interpreted as a dialectic about the nature of society or history in the language of Hasan Hanafi, where theology is intended to uncover new socio-political dialectics originating from modern culture. Therefore, the 
Press, 1983.

reconstruction of the belief system is aimed at confronting new threats which use the main doctrines to maintain their purity in history. Dialectics does not only stop at words or acts. It does not only consist of concepts and arguments between individuals, but also the dialectics of various societies and nations and conflicting interests. The new conceptual framework is based on the responsibility of the reconstructed theology. The new construction of the theological belief system is intended to meet the hopes and successes of the Islamic world such as; independence, social equality, identity and progress of the people and nation. Thus, Muhammadiyah's political theology is socio-political hermeneutics, which reflects social-political conflicts, through reading the various interests of existing sociopolitical groups, and then defending them within the frame of a pure belief system (tajrid and tajdid).

\section{CONCLUSION}

Muhammadiyah as a religious organization with millions of participants in Indonesia and abroad has made various efforts in the moderation in Indonesia. Through the theological concepts of Islamic Progress, which include; Darul Ahdi wa Syahadah, Islam Wasatiyah and Cultural Da'wah produced by Muhammadiyah as an ideology of thought and movement, will certainly change the epistemic blocks and religious behavior of the people (basic structure) of Indonesia. The theological concept is certainly as part of Muhammadiyah's religious transformation in response to various forms of ideology that are not in accordance with Muhammadiyah's manhaj and the pluralistic character of Indonesian society.

\section{REFERENCES}

[1] M. Nakamura, Bulan Sabit Muncul Dari Balik Pohon Beringin. Yogyakarta: Gadjah Mada University
[2] A. Jainuri, Muhammadiyah Gerakan Reformasi Islam di Jawa Awal Abad Keduapuluh. Surabaya: Bina Ilmu, 1987.

[3] D. Noor, The Modernist Muslim Movement In Indonesia 1900-1942, Cetakan 1. Jakarta: LP3ES, 1980.

[4] A. N. Fuad, Dari Reformis Hingga Transformatif. Malang: Intrans Publising, 2015.

[5] Kementerian Agama RI, Moderasi Beragama. Jakarta: Badan Litbang dan Diklat kementrianAgama RI, 2019.

[6] E. B. dan I. M. Lapidus, Islam, Politics and Social Movement. Berkeley: Los Angeles and London University of California Press, 1988.

[7] Karl Mannheim, Ideologi dan Utopia, Kaitan Pikiran dan Politik. Yogyakarta: Kanisius, 1991.

[8] A. K. Alpha Amirrachman, Andar Nubowo, Ed., Islam Berkemajuan Untuk Peradaban Dunia, 1st ed. Bandung: Mizan, 2015.

[9] P. P. Muhammadiyah, Negara Pancasila Sebagai Darul Ahdi Wa Syahadah. Yogyakarta: PP MUhammadiyah, 2015.

[10] H. Nashir, Indonesia dan Keindonesiaan Perspektif Sosiologis, 1st ed. Yogyakarta: Suara Muhammadiyah, 2019.

[11] P. P. Muhammadiyah, Dakwah Kultural Muhammadiyah. Yogyakarta: PP Muhammadiyah, 2004. 